\title{
Peasant Livelihoods and Land Degradation: Evidence from a Participatory Assessment in the Gia-Kajelo Community in Northern Ghana
}

\author{
J. A. Yaro \\ Department of Geography and Resource Development, University of Ghana, Legon, Accra, \\ Ghana
}

\begin{abstract}
The relationships between peasant livelihoods and land degradation in the Gia-Kajelo community were examined in a wider context of the man-environment relations in the African savanna. The relationship has to be looked at in a wider dimension involving conceptual frameworks that incorporate contemporary understanding of rural livelihoods, institutional dynamics, resource diversity, environmental variability and macro level influences on local socio-politicoeconomic landscapes. Investigating these relationship should move from the biased technocratic objective assessment of virgin lands and so-called mapping of human impacts to studies identifying the environment as an arena for synergistic interaction between 'man' and 'nature'. Based on the later approach results showed that all wealth groups experienced land degradation on their fields, reflecting the type of land investments made and mediated by levels of access to resources and opportunities. Being poor reduced the ability of most people to invest in land improvement, but being rich did not automatically lead to good environmental health.
\end{abstract}

\section{Introduction}

The influential report by the Brundtland Commission in 1987 formally stated the povertyenvironment hypothesis, which blamed the environmental problems in the Third World on poor people. The hypothesis explains that poverty leads to population growth, due to the desire of poor people to invest in more children as a source of economic and social security. A Malthusian spectre follows this increase, whereby land fragmentation, depletion of soil fertility, wood lots and other biophysical resources lead to migration and colonisation of hitherto marginal land. This in turn leads to a fall in food production, declining standards of living and hence poverty (Dasgupta \& Måler, 1996). Environmental destruction and poverty reinforce each other; the poor are both the agents and the victims of environmental destruction (WCED, 1987). Growing populations, over-dependence on land resources, weather vagaries and falling incomes form the basis of the bleak picture painted by environmental pessimists (Eckholm \& Brown, 1977; Brown, 1989; Ehrlich \& Ehrlich, 1990; Brown \& Hal, 1994).

Economic growth is needed to break the poverty-environment downward spiral. The slogan of the World Bank and others are «win-win» policies designed to promote economic growth and also benefit the environment (Taylor \& Mackenzie, 1992; Abdulai \& Delgado, 1995). This is partly because economic growth is assumed to reduce poverty and, therefore, enhance environmental conservation (World Bank, 1986; Biswanga \& Landell-Mills, 1995). The policies advocated by World Development Report 1990 and UNDP-sponsored Human Development Report (Maxwell, 1996) involving labour intensive economic growth with targeted safety nets, promoted by 'market friendly' state policies and limited roles for state bureaucracies, key roles for institutions of civil society and recognition of the influence of international factors in achieving sustainable economic growth with poverty alleviation (World Bank, 1990) testifies to the consensus on the link between poverty and environmental degradation.

Others have contested the population issue by showing evidence of population increases stimulating innovations in agriculture through technological and institutional changes (Boserup, 1965; Lein, 1993). The green revolution in Asia lent support to a Boserupian-intensification and the policy-led intensification advocated by Lele \& Stone (1989) and capital-based intensification advocated by Matlon \& Spencer (1984). Inequality in access to land and the investment patterns of large landowners, neither of which depends on population pressure, is the core of the 
widespread environmental destruction (Stonich, 1993). Economic and political marginalisation of peasants, resulting from expanding capitalist relations of production, displaces and sets in motion a process of impoverishment and environmental degradation. This forces them to adopt survival strategies and making certain land use decisions that destroy the environment. They are, thus, executioners of the final task dictated by external and internal factors (Chambers, 1983; Blaikie, 1985; Carney \& Watts, 1991).

Without lapsing into the sectional ideological debates of the two camps above, this article examines the livelihood strategies of different wealth groups and their real and perceived impacts on land degradation in the Gia-Kajelo community within the broader debate of sustainable rural livelihoods. The effects of land-based livelihood activities, macro level forces and institutional factors on the maintenance of environmental quality and sustainability are assessed. The research shows that all land-based livelihood activities had both positive and negative effects on the environment irrespective of whether they are employed by the poor or the rich. Variation in magnitude of impact is the substantive issue between the two groups.

Theoretical framework

\section{Materials and methods}

There has been a conceptual shift from 'man versus nature' perspective to a 'people in places' paradigm allowing the experiences of people in differentiated environments influence analysis of social phenomena (Forsyth \& Leach, 1998). In common parlance the concept environment is a synonym for nature, emphasizing the man/nature dichotomy deliberated upon in many academic disciplines (Little, 1999). Envisioning the environment differently provides an avenue to subjectively analyse environmental problems associated with the preferences of people living in specific geographical spaces (Chambers, 1994; Boyd \& Slaymaker, 2000; Cavendish, 2000; Agrawal, 2001; Lambin et al., 2001).

A first step in understanding land degradation involves assessing the livelihoods of peasants recognizing the fact that they wish to continue making a living from the resources and activities they engage in. The concept of sustainable rural livelihoods examines the social dynamics of livelihoods and the interactions between the actors and the natural resource base. A livelihood comprises the capabilities, assets (both material and social resources), and the activities required for a means of living. A livelihood is sustainable when it can cope with and recover from stresses and shocks, maintain or enhance its capability and assets, while not undermining the natural resource base (Chambers \& Conway, 1992). Sustainability is defined as 'the ability of a system to maintain productivity in spite of major disturbance, such as is caused by intensive stress or a large perturbation (Ahmed \& Lipton, 1997).

It is important to understand the opportunities and constraints to sustainable livelihoods. Access to endowments related to achieving entitlements has repercussions for sustainable livelihoods, poverty and environmental quality. Man-environment interactions are mediated by rules and norms, which are continuously changing in reflection of wider and more powerful factors such as markets, government and donor policies, weather fluctuations and other biophysical changes. The role of institutions is, however, not deterministic as the struggle between structure and agency in the social sciences show. Both can be argued to have their historical latitudes during which one gives way to the other.

Globalisation or interconnectedness of the community to other places through markets, information, policy formulations and capital flows, among others (Lambin, et al., 2001), is increasingly altering local conditions and determining land use, ownership patterns, access patterns and social capital. Peasant livelihoods are outcomes of ecological, economic and political interactions, suggesting that any one-sided analysis of processes in each of the three broad domains is bound to fail in constructing reality. Political ecology research programs incorporating 
ecological concerns with wider political economy set the pace for an anthropocentric analysis of environmental issues.

\section{Gia-Kajelo community}

The Gia-Kajelo community falls within the Kasena-Nankani District of the Upper East Region, which is located in the north-eastern part of Ghana (Fig. 1). Agriculture is the main economic activity, with a small percentage engaged in white-collar jobs and activities such as artefactmaking, wood cutting, quarrying and traditional medicine. It falls within the Guinea savanna vegetation belt described as fire-swept grassland of varying heights occurring between deciduous trees, which mostly have economic and social values (Dickson \& Benneh, 1970). The area falls within the tropical continental climatic zone characterised by pronounced wet and dry seasons. The single rainy season with monthly totals increasing gradually from March to September forms the period when peasants have to make most of their livelihoods. On the average, a rainfall amount of $1100 \mathrm{~mm}$ is received (Department of Geography and Resource Development, 1992).

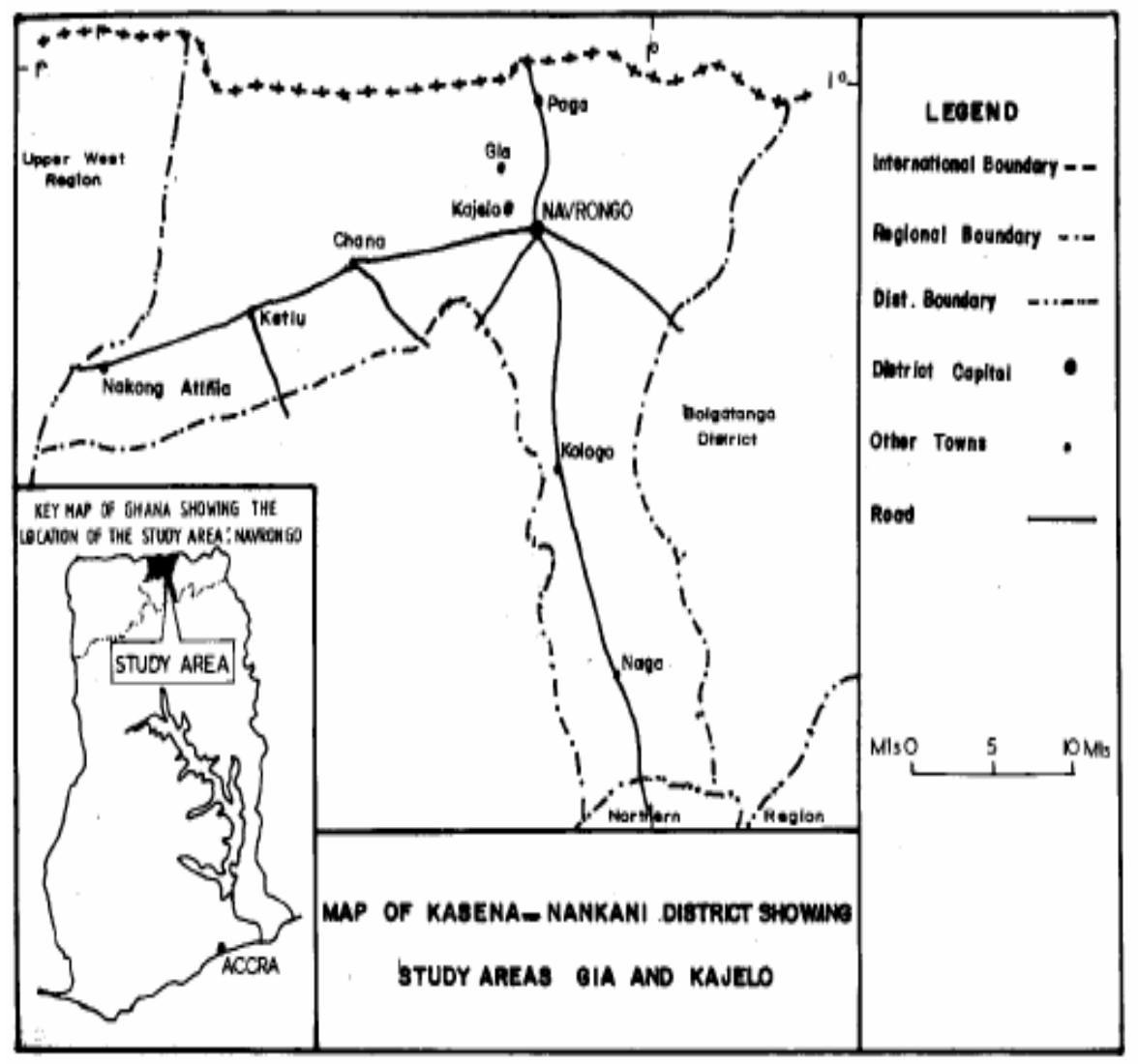

Fig. 1. Map of Kessena-Nankani District showing study sites

The biophysical resources available include loamy soils, woodlands containing wildlife and wild fruits, which constitute their primary endowments in addition to their human capital and social capital. Exchange entitlements are crucial to the well-being of peasants, indicating the degree of integration of the peasantry to the national and global markets. The remoteness of the District from the national capital, its poor productive forces resulting from colonial neglect and policies of post-independent governments, combined with its political inarticulateness, has imposed a regime of nature-dependency with few opportunities for making livelihood outside 
agriculture and forestry. Almost $90 \%$ of lands around the villages are cultivated continuously (focus group discussions), reflecting shortage of lands due to the high population density of 126 people per square kilometre (own calculation using year 2000 population estimate).

Both labour-based intensification and capital-based intensification are evident on farmlands ranging from the intensive weeding regimes, mound-building around individual sorghum and millet plants, crop watering during the dry season, mulching, manure processing and spread application to the use of bullock ploughs for cultivation, application of chemical fertilizers, construction of wells and the use of the donkey carts for transport. With the decline of both crop yields and real prices of crops, the need to increase income from other activities to enable them buy imported food and pay for public services has led to concomitant surges in investments in livestock rearing, commercial harvesting of fuel wood, fishing, hunting, and arts and crafts that rely on natural resource harvesting. Other income-generating activities that did not directly result from natural resources include retail services, beer (pito) brewing, weaving, selling cooked food and white-collar jobs.

\section{Primary data}

Data used in this study was collected between June-August 1999 and in June 2002 in the twin villages of Gia and Kajelo, referred to as the Gia-Kajelo community, using both qualitative and quantitative methods, and environmental assessments of village lands. A survey covering 60 house-holds was conducted in 1999. Traversing of village lands orthogonally, in addition to visiting farmlands of three rich and three poor farmers located in valleys, uplands and sandy lands, was conducted. Four focus group discussions were organised in each village with discussions centred on poverty, land management, land tenure, environ-mental processes, perceptions of land degradation, gender roles in production and wealth ranking. Intensive household interviews were held with 15 households in August 2002. Households were classified into four wealth groups; the rich, the better-off, the moderate poor and the ultra-poor (Fig. 2). The moderate poor formed the majority of the population while the other three categories together constituted $50 \%$.

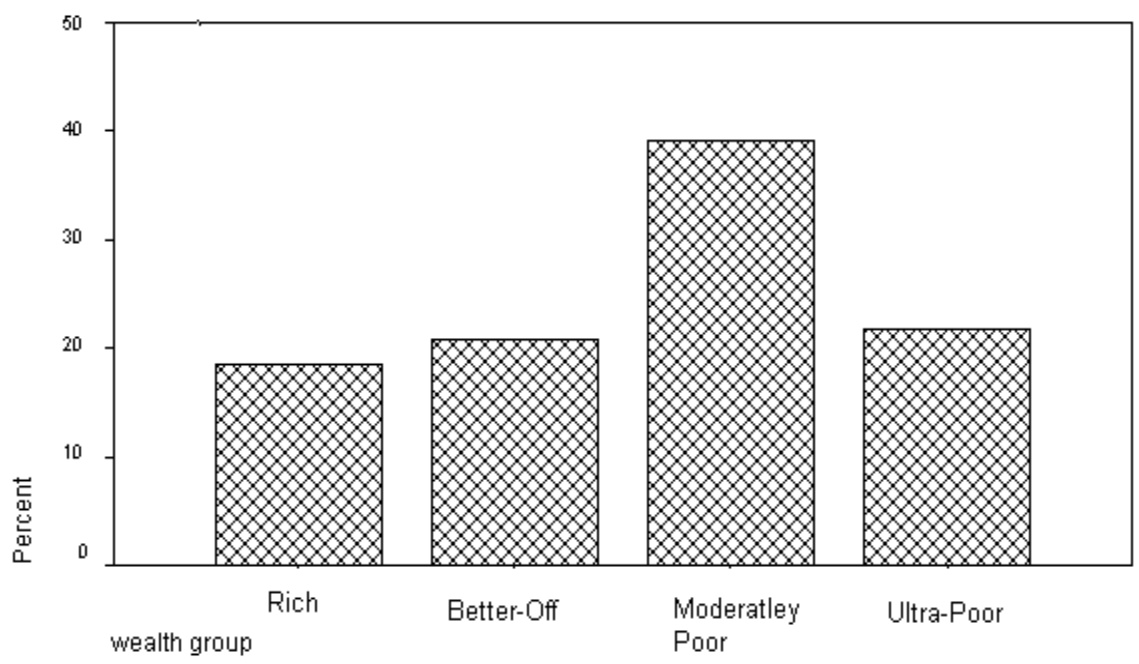

Fig. 2. Wealth groups in the Gia-Kajelo Community. Source: fieldwork, 2000

The rich group are mostly people who have inherited large areas of land in fertile locations, inherited cattle from parents and grandparents, or are pioneers in the irrigation project, as well as 
teachers, extension officers, stenographers and watchmen. Farmers in this group normally concentrate on crops such as rice and groundnuts in the rainy season and tomatoes in dry-season gardening. The better-off are food-secure to a large extent and less vulnerable than the poor, but they are not able to meet all their needs. They are able to feed their families, purchase inputs for farmland, cultivate at the appropriate time, harvest at the right time, and store their produce until prices rise. The moderate-poor group have few resources or endowments for participation in productive activities. Almost every investment decision of the moderate- poor man is a gamble. The ultra-poor group are the poorest people in the community. The parcels of land owned by this group are usually inherited, and only the lucky ones have theirs on fertile sections. The common asset for this group is poultry.

\section{Perceptions of land degradation in Gia-Kajelo}

Land degradation (translated by peasants as 'earth destruction' or tiga chogim) to the peasants is the inability of nature to keep supplying the needed environmental resources for human use. Soil infertility, deforestation, reduction of wild fruits and wildlife were the main forms of land degradation identified through the interviews (Fig. 3) and confirmed by the environmental surveys. The rich and the better-off see soil infertility as the most destructive to livelihoods because they own huge lands, which they cannot afford to fertilize and have to make trade-offs. There was no consensus on the detrimental effects of deforestation. The bush fallow system is argued to cause changes in land use and not degradation while commercial fuelwood cutting involving the use of green vegetation was considered as degradation by all wealth groups. Scarcity of wood resources implied degradation, which is blamed on fuelwood cutting of the poor and the farming practices of rich groups. To the ultra-poor everything was wrong with the environment, hence, no need to point fingers at certain forms of land degradation.

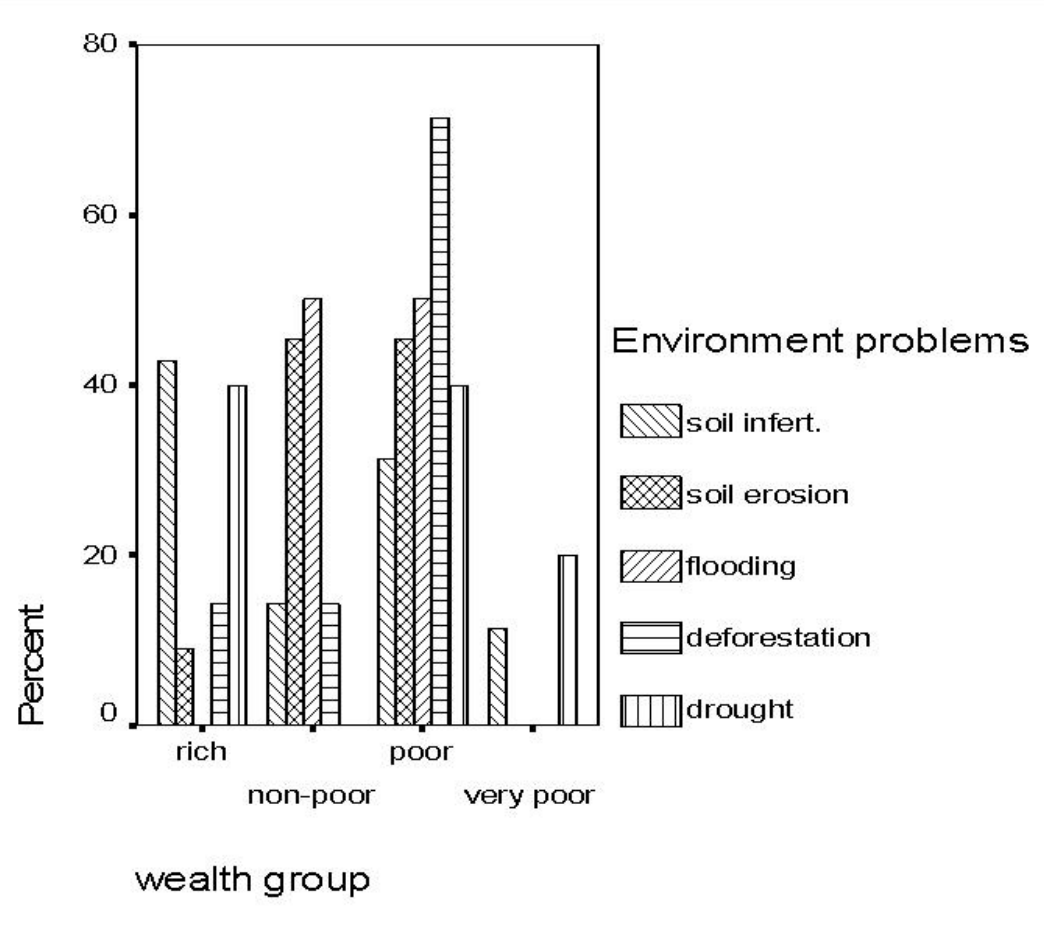

Fig. 3. Major forms of land degradation in Gia-Kajelo Source: Fieldwork, 2000. 
Declining soil fertility is reflected in the falling yields of major staples such as millet (reported during focus group discussions in both villages). Farmers switch to crops such as cowpeas and groundnuts that require less fertilizer and which also have high commercial values and yields to compensate for cost of fertilizing. Some elderly farmers claimed they could tell the level of fertility from the colour and texture of soils and concluded that almost all village lands have experienced falling soil fertility. New lands brought into cultivation performed badly after 2 years of cultivation, obviously the reason why the older generation did not cultivate them. Deforestation is widespread on common property lands. Strangely, tree density was increasing on cultivated land when air photos for 1962 and 1990 were compared (Yaro, 2000).

Environmental traverses revealed new tree species such as mango, neem, cashew, guava, pawpaw and wild fruit trees, in addition to the traditional valuable trees such as the shea, dawadawa, and kapok trees protected by social rules from being cut. Associated with deforestation is the disappearance of wild game and wild fruits. Hunters travel long distances towards the Upper West Region to hunt. Wild fruit trees are protected by traditional institutions, but bush fires and the lack of human efforts to replace these trees due to traditional believes, has led to dwindling numbers dominated by very old trees.

Soil erosion was difficult to characterise because most farmers, both young and old or rich and poor, argued that gullies were a necessary component of the landscape by providing safe corridors for water flow. However, sheet erosion that results in devastating fertility lose was acknowledged by all as serious. Others contended that gullies and rills reduced their landholdings and, hence, productivity. All forms of soil erosion could be found everywhere on cultivated areas, fallowed land, and on common property. Frequency of gullies is highest on common property reserves while splash erosion and rills are higher on cultivated areas. The lower number of gullies on farms is the result of conservation practices involving the use of the hoe, which is known to prevent erosion. The higher density of grass on common property lands protects the soils from splash and rill erosion, but not gullies that are very wide and develop mostly along topographical faults and footpaths (source: environmental transects).

\section{Livelihood activities and access to resources in Gia-Kajelo community}

Households in the study villages engage in farm or/and non-farm activities or eventually outmigrate. The farm sector comprises field cultivation, animal rearing, and gardens during the dry season and irrigation plots. The non-farm sector is composed of all non-agricultural activities such as employment sources in public and private spheres, self-employment in trading and manufacturing, and the extraction of natural resources. Livelihoods in the study villages are regulated by the dry and the wet seasons, with the wet season being the domain for farm activities, while the dry season abounds with non-farm activities. Qualitative interviews showed that in the 1970s most households only engaged in natural resource gathering activities for noncommercial purposes during the dry season. This trend has changed, as most households are now busy during the dry season gathering fuelwood, burning charcoal and gathering wild fruits for sale in the urban and village markets. Pushed to the margins of excruciating poverty household members out-migrate to the south of the country in search of farm work or menial work in urban areas.

Livelihood activities are used in different intensities and combinations according to the wealth status of the household and its environmental resources. A livelihood in the Gia-Kajelo community is built on prioritising a balance between income and expenditure of the household and the individual. There has been a concentration on farming and natural resource related income-earning activities to meet the rising expenditure patterns imposed by structural adjustment policies. A historical overview of Ghana's economic path from the early 1980s is appropriate in understanding the livelihoods portfolios and orientations of peasants. From 1983 onwards the country came under the Economic Recovery Program (ERP). The ERP marked the start of structural adjustment in Ghana designed as a reaction to external and internal shocks 
unfavourable to the economy (Ampadu-Agyei, 1988; Seini, 1992; Songsore, 1992). Some policies associated with the program included the elimination of subsidies, increasing diversification of export crops, the introduction of user fees in educational and health sectors, removal of price regulations and foreign exchange control, and the removal of restrictions or tax barriers on imported products.

The elimination of subsidies led to increases in prices of inputs for farming which led to a reversal of gains made in the adoption of modern farming methods in the 1970s that mitigated the effects of population growth. The consequence has been falling food production from overcultivated lands that are continuously being degraded from over-cultivation. Complete withdrawal of subsidies crippled several spheres of the economy that, hitherto, had reciprocal links with agriculture. Also, the need to produce food crops to feed the spiralling urban population resultant from rural-urban migration led to high pressure on land resources.

The rise in demand for land led to the alienation of poor farmers to poor or marginal lands. A case in point is the Tono Irrigation Dam that pushed poor farmers unto marginal land or overcultivation regimes on compound farms. Population pressure has led to land fragmentation that causes continuous cropping with variable or no use of fertilizers (focus groups 1999). Land ownership in the area is highly unequal showing the destitute with no lands while small percentage of households own over six acres (Table 1). Two ultra-poor households with large lands were ageing ones but due to low levels of returns from agricultural lands the lending land does not improve their livelihoods significantly. Borrowing of land by relatives and friends only leads to enrich-ment of borrowers and few environmental investments.

TABLE 1

Landholdings in Gia-Kajelo community by wealth group

Size of land
None
$1-2 \mathrm{ac}$
$3-4 \mathrm{ac}$
$5-6 \mathrm{ac}$
$7-8 \mathrm{ac}$
9 and above
Not stated
Total

\begin{tabular}{lll}
\multicolumn{3}{c}{ Wealth groups } \\
Rich & Non-poor & Poor \\
2 & 3 & 1 \\
1 & 2 & 5 \\
6 & 3 & 8 \\
3 & 2 & 6 \\
3 & 1 & 0 \\
2 & 0 & 1 \\
2 & 1 & 3 \\
19 & 12 & 24
\end{tabular}

$\begin{array}{ll}\text { Ultra-poor } & \text { Total } \\ 1 & 7 \\ 2 & 10 \\ 0 & 17 \\ 0 & 1 \\ 2 & 6 \\ 0 & 3 \\ 0 & 6 \\ 5 & 60\end{array}$

Average land holding per household in the two villages is 2.1 acres that has to produce subsistence crops and market crops to cater for an average of five persons per household (Table 1). The result of the pressure on land is the reduction in soil fertility. This is identified as the most devastating form of land degradation and blamed directly for the growing poverty among peasants. Calculating expansion of cultivation using air photos and satellite images for 1962 and 1990, respectively, it is realised that compound farms experienced an expansion of $42.97 \%$ between the period, while bush farms declined by $46.74 \%$ and tree savanna or woodlands declined by $16.17 \%$ (Yaro, 2000). The District experienced a marginal increase in population from 93,397 in 1960 to only 99,006 in 1970; a percentage increase of 6.0\% over the 1960-1970 intercensal period (Geography and Resource Development Report, 1992). The annual growth rate was only $0.6 \%$. The 1984 census put the population at 149,680, indicating an intercensal increase of $50,674(51.2 \%)$ and an annual growth rate of $3.0 \%$. The population has subsequently fallen to 149,491 in the year 2000 housing and population census (GSS, 2002). This is due to outmigration rather than fallen fertility. 
The picture between the 1960s and 1980s contradicts the widespread belief that population growth automatically results in extensification. There has been an intensification of agriculture around the settlements on compound farms and previously rotated bush fallows. Out-migration plays an important role in reducing the effect of rising population in addition to intensification as shown by the fallen population between 1984 and 2000. Also, high cost of tractors and labour limits the extensification drive that was prevalent in the 1960s funded by the Nkrumah Government. The Tono Irrigation Project is a source of major ownership for about $30 \%$ of the villagers. Having access to an irrigation plot for vegetable and rice cultivation, the most profitable and suitable, is linked not only to ability to pay for the services, but also to 'whom you know'.

Hardly do you find an ultra-poor person on the project though initially most of them cultivated small plots on the project. The cost of fertilising, land fees and gaining access through the bureaucratic system excludes most poor people. Agro-forestry plots are comparatively new with no defined ownership as peasants feel the land is theirs while the trees belong to the NGO with fruits accessible to so-called 'members'. Most uncultivated lands are unsuitable for farming, but good enough as pasture, the natural growth of wild fruits and as habitats for wildlife. This could be regarded as the common property resource reserve accessible to every peasant.

The reflection of these combinations of factors can be seen partly in reported status of farm conditions by different wealth groups (Table 2). Fallen tree densities on farms is common across farms of all wealth groups but more evident on the case of the poor and ultra-poor. Fuelwood cutting as an off-farm income activity explains this pattern where poorer groups are more likely to exploit fuelwood from their farms for sale or clear trees to increase area available for crop cultivation since land sizes are small. The ability of farmers to control rill erosion is dependent on cultivation method and labour availability for contour bunding (focus group discussions). Wealthier groups used more bullock ploughing techniques and tended to have more labour sources than the poorer groups, hence, the low incidence of rills on their farms.

\section{TABLE 2}

Farm condition of different wealth groups in the Gia Kajelo community

\begin{tabular}{llllll}
\multicolumn{7}{c}{ Wealth } & groups & & & \\
Farm condition & Rich & Non-poor & Poor & Ultra-poor & Total \\
Few trees & 7 & 6 & 10 & 4 & 27 \\
Rills everywhere & 4 & 2 & 5 & 0 & 11 \\
Mixed and varied & 8 & 4 & 9 & 1 & 22 \\
Total & 19 & 12 & 24 & 5 & 60
\end{tabular}

Free market policies have also meant elimination of import taxes supposed to make the local producers competitive and efficient through a 'slow grow up' process. Unfortunately, the dumping scenario the country has witnessed since the inception of this policy has crippled local industry and agriculture. Importation of rice from Asia and the USA has led to the abandonment of many rice farms in northern Ghana; among them is the well known Nasia Rice Company. The non-humanistic, but econo-mistic policies have mainly benefited the export sector and firms engaged in importing foreign products for the urban populace to the detriment of the ubiquitous peasant. The most impor-tant rises in expenditure are reported health for all wealth groups, while the poorer groups identified rising food prices as a major problem to livelihoods (Table 3). This is an indication of poor agricultural produc-tion that must be comple-mented by food purchases through exchange using cash crop and livestock. 
TABLE 3

Rising expenditure sources in the late 1980s in the Gia-Kajelo community

\begin{tabular}{lrrrcc} 
Increased expenditure & \multicolumn{5}{c}{ Wealth groups } \\
& Rich & Non-poor & Poor & Ultra poor & Total \\
Health & 11 & 10 & 10 & 5 & 36 \\
Food & 0 & 2 & 6 & 0 & 8 \\
Clothing & 0 & 0 & 1 & 0 & 1 \\
Farming & 0 & 0 & 2 & 0 & 2 \\
School fees & 5 & 0 & 1 & 0 & 6 \\
Building materials & 0 & 0 & 2 & 0 & 2 \\
Not stated & 3 & 0 & 2 & 0 & 5 \\
Total & 19 & 12 & 24 & 5 & 60
\end{tabular}

Source: Livelihood survey in villages

Years of land fragmen-tation, out-migration and changing institutional rules to land acquisition involving monetary transactions preclude the poor from accessing more lands. Some landlords require a cow and some cash to lease out land permanently for cultivation in contravention of the traditional kola nut, cowry and tobacco required by tradition. There is increasing monetisation of land transactions for both residential and cultivation purposes. Mitigating the effects of falling incomes is mainly through reducing expenditure levels on production and household upkeep. Land management strategies that seek to reduce expenditure include reduction in fertilizer application, selection of specific crops and land types for fertilising, single weeding regimes, burying grass and other residue for compost manure, fire clearing of farms, usage of family labour as substitute for machinery, early harvesting before maturity to break the hunger season and the formation of alliances with other farmers to help in cyclical labour distribution (focus groups 2002). Expenditure-reducing strategies are the commonest because of the widespread nature of poverty and the necessity to protect the resource base.

Poverty of the peasant is their inability to feed their family all year round, educate or meet the health needs of their children, buy inputs for their farm work, live under a strong roof and contribute in discussions that have a bearing on her/his future and generations to come. People are loosing these rights day in day out as their purchasing power and social status decline due to increasing vulnerability of the society in general. The degree to which peasants experience these trends varies greatly reflecting the wealth differentiation among them.

Sustainable livelihoods are derived from peoples' capacity, enabled by their entitlement sets, which result from endowments that are shaped by institutions at various levels of society (Behnke \& Scoones, 1993; Leach \& Mearns, 1996; Beck \& Nesmith, 2000). Access to resources in GiaKajelo is defined by both traditional land tenure and power relations within the village and formal rules in the form of district by-laws and national forestry and land laws. Changing access patterns to lands has its roots in population induced land fragmentation, demand related pressure, appropriation of land by government for irrigation and forestry, non-equitable allocation patterns of family land by some greedy landlords bedevilled by favouritism, and land sales by land chiefs and chiefs in response to urban sprawl, and the subsequent commoditisation of land.

\section{Investment activities and land degradation}

Investments in crop cultivation, animal husbandry, and natural resource harvesting using inputs such as labour, equipment, capital and fertilizers keep the productive wheel rolling. The 
availability of these investment resources determines the sustainability of strategies adopted by peasants in maintaining their livelihoods. Peasants will invest in activities and assets that improve their incomes, and also broaden their livelihood base, thereby, allowing a broader manipulation. The most important investment items were increases in farms sizes or the cultivation of specific crops, purchases of livestock and the creation of social safety nets. Livestock stood out as the most important source of security because of the ease of conversion to food, inputs for farming and cash.

What are the most destructive investment patterns? Who engages in these investment activities? How do they perceive their impact on the environment? The investment patterns of the people have both positive and negative effects on land quality. The degree to which each wealth group engages in a particular activity determines the amount of land degradation or aggradation they cause (Tables 1, 2 and 3). This degree is shown by the rank assigned by the villagers to each wealth group. The lowest rank being * (1) and the highest being **** (4), with - showing absence or 0 level of involvement.

Tractor ploughing helps farmers put in place an effective way of checking soil erosion and controlling drainage. It also aids in bringing up soil nutrients that are leached but still within reach of the plough in addition to producing compost through the covering of grass and debris. At the same time tractor ploughing necessitates large removal of trees and stumps that post a hazard to the expensive ploughs. Continuous ploughing also leads to loose and infertile soils as a result of the destruction of the structure of the soil.

Gardens are examples of agricultural intensification of a Boserupian type. Farmers get to understand many aspects of farm production such as drainage, nutrient recycling, crop tendering and soil manipulation using these small units as experimental learning environments. At the same time garden construction has been a source of land degradation when it is considered in a placebased perspective. Manure and debris that would have been used to fertilise compound and second ring farms are transferred to garden beds, which are often overdosed to ensure maximum output. Secondly, it reduces the variety of energy sources for cooking by using stalks and stems for fence construction, thereby, pushing women to cut trees to supplement household energy needs. Thirdly, in the beginning of the rainy season debris from garden structures are swept into the irrigation dam and other drainage channels. The irrigation authority has blamed the increasing siltation of the Tono dam on garden activities of the people. Construction of gardens on the valley of the Tono river when it recedes in the dry season is largely responsible for this trend. Gardens located far away from rivers and dams make use of water from wells and do not contribute to this trend but may reduce the water table.

Investment in new crop varieties, though promising in terms of higher output and suitability to initial conditions, in the long run may cause the exhaustion of most soils without adequate inputs. These are mostly new varieties of sorghum, maize, cowpeas and cotton that require chemical fertilizers and, in most instances, involve the use of the tractor and bullock ploughs which also have their dark sides. Most farmers claimed that the destruction of the soil structure and the subsequent sandification of the soil is a result of the use of chemical fertilizers.

The rearing of livestock, in general, leads to the production of manure and availability of cash income for the purchase of farm inputs. A majority argued that cattle are the best in terms of production of manure, while goats served best in clearing the landscape as a preventive measure against bush fires. Cows and sheep, they say, are selective in grazing and do not over-graze because they leave out unwanted grass species. Goats, on the other hand, will eat anything provided the desired species are exhausted. Poultry was not blamed for any destructive activity but rather seen as eco-compatible. Livestock hardly lack grass to feed except during drought years when the long dry season gives rise to bush fires that destroy pasture (general opinion in both villages). The issue of overgrazing is contestable in the study area. Bush fires have been 
argued to destroy pasturelands during the dry season. Animal numbers per household correspond to labour requirement for tethering during the cropping season. This has a limiting impact on number of livestock owned.

Non-farm activities also have spin-off effects on land degradation. Local beer production (pito brewing) had negative impacts on the environment as it competes with household for supply of sorghum and millet, necessitating the expansion of production mostly in the form of extensification of agriculture. Pito consumption leads to alcoholism, which, in turn, leads to a reduction in household resources and assets. Most alcoholics might be smokers at the same time, which increases the incidence of bush fires.

Shea butter (butter from the nuts of the shea tree) and dawadawa (condiment from dawadawa tree) processing which depend on nature for their raw materials have formed the core of local industry for centuries. The shea and dawadawa trees grow naturally and are protected against bush fires and farming activities of land managers. Only dry portions of these trees are used as fuel wood and, therefore, help ecological soundness since they are protected.

Fuel wood cutting is probably the most obvious activity that leads to land degradation. Cutting trees used to be limited to dry branches and fast growing shrubs, but rising urban demands has included green trees and, hitherto, unwanted species. The shortage of dry trees and the distance involved in travelling to where these are found make people resort to cutting branches of green trees. Cutting of green trees is rampant on communal land that is out of range of monitoring. The land chief only realises after a week or two that some trees have been cut on communal lands, and it is often too late for any protective action to be taken.

All groups engage in activities that have a double effect on the quality of their environments. Judging from Tables 1, 2, and 3, the rich and the better-off fall into many of this double effect category. They have a 100\% involvement in tractor ploughing, gardens, cattle and sheep rearing, with minimal representations in tree planting, alcoholism and woodcutting. They are both destroyers and builders of the environment. What is difficult to measure is the net effect of their activities. The individuals within each group had different net effects on the environment depending on the time or season, degree of adherence to institutions and the prevailing socioeconomic atmosphere. The bush fallow system practiced by the rich and the better-off (Table 4) obviously causes deforestation, while crop rotation with maximum use of manure and chemical fertilizer on farmlands close to settlements ensured good soil management. Bush fires benefit this group by opening up more areas for cultivation.

TABLE 4

Livelihood activities of the well-off and the relationship with land degradation

$\begin{array}{lllll}\text { Wealth group } & \text { Ravestment item } & \text { Rank } & \text { Positive effect } & \text { Negative effect } \\ \text { The rich } & \text { Farm management: } & & & \\ \text { and the } & \text { Manure } & * * & \text { Good soils } & - \\ \text { better-off } & \text { Fertilizer } & * * * & \text { Increase fertility } & \text { Bad soils subsequently } \\ & \text { Hoe and bullock ploughing } & * * * * & \text { Good soil structure } & - \\ & \text { Tractor ploughing } & * * * & \text { Check erosion } & \text { Loose soil, devegetation } \\ & \text { New crop varieties } & * * * & \text { Suited to soil } & \text { Exhaust soil fertility } \\ & \text { Tree planting } & * & \text { Improve climate \& soil } & - \\ & \text { Erosion control- bands, } & * * & \text { Good soil } & \\ & \quad \text { furrows } & & - & \text { Affects other places: }\end{array}$




$\begin{array}{clll}\text { Cows } & * * * * & \text { Manure, ploughing } & \text { Reduces vegetal matter } \\ \text { Sheep } & * * * * & \text { Manure } & \text { Not very bad } \\ \text { Goats } & * * * & \text { Manure } & \text { Overgrazing } \\ \text { Poultry } & * & \text { Manure for vegetables } & - \\ \text { Pito brewing } & * * & - & \text { Extensification } \\ \text { Alcoholism } & * & - & \text { Bush fires } \\ \text { Shea butter making } & * * & \text { Protection of shea trees } & \\ \text { Dawadawa making } & * * & \text { Protection of dawadawa } & \\ \text { Wood cutting } & * & - & \text { Devegetation }\end{array}$

Source: Fieldwork, 2000

The wisdom of private property systems might be the overriding factor here, as the rich see compound and second ring farms as fixed property while the bush lands can change ownership overnight. Lack of strict institutional rules governing bush lands is blamed for this conception. Access to labour from other wealth groups allowed these groups to implement several water and soil conservation technologies, such as multiple weeding with heaps around individual crops, blocking or opening water channels, and carrying manure over considerable distances. A spread effect they have on poorer groups is helping them with ploughing, seeds and tools for digging wells.

The moderate poor intensified production both on compound and second ring farms with few of them having bush farms (Table 5). The compound farms are well fertilised from manure and other household debris, while a little amount of chemical fertilizer is used on second ring farms. The soils are often very impoverished except on fields with commercial crops such as maize, cotton and cowpeas where fertilizers are applied, funded by livestock sales or cotton companies. Some have benefited from NGO activities in planting trees on their farms, which helps the environment and also provides them with income and food from fruits, with the potential of being used as fodder for livestock and future fuel wood. Soil and water conservation strategies are widespread among larger households. The more people a household had the lesser the amount of erosion on their lands.

TABLE 5

Livelihood activities of the moderate-poor and the relationship with land degradation

\begin{tabular}{|c|c|c|c|c|}
\hline \multirow[b]{2}{*}{ Wealth group } & \multirow[b]{2}{*}{ Investment item } & \multicolumn{3}{|c|}{ Environmental impacts } \\
\hline & & Rank & positive effect & Negative effect \\
\hline \multirow{17}{*}{$\begin{array}{l}\text { The } \\
\text { moderate } \\
\text { poor }\end{array}$} & On farm & & & \\
\hline & Manure & $* *$ & Good soils & - \\
\hline & Fertilizer & $*$ & Increase fertility & Bad soil \\
\hline & Hoe and bullock ploughing & $* *$ & Good soil structure & - \\
\hline & Tractor ploughing & & Check erosion & Loose soil, devegetation \\
\hline & New crop varieties & $* *$ & High yields & Exhaust soil \\
\hline & Tree planting & $* *$ & Improve climate \& soil & - \\
\hline & $\begin{array}{l}\text { Erosion control- bands, } \\
\text { furrows }\end{array}$ & $*$ & Good soil & - \\
\hline & Garden construction & $* * * *$ & Good management skills & Affects other places \\
\hline & Livestock rearing & & & \\
\hline & Cows & $*$ & Manure, ploughing & Reduces vegetal matter \\
\hline & Sheep & $* *$ & Manure & Not very bad \\
\hline & Goats & $* * * *$ & Manure & Overgrazing \\
\hline & Poultry & $* * * *$ & Manure for vegetables & - \\
\hline & Non-farm & & & \\
\hline & Pito brewing & $* * *$ & - & Extensification \\
\hline & Alcoholism & $* *$ & - & Bush fires \\
\hline
\end{tabular}




$\begin{array}{llll}\text { Shea butter making } & * * * & \text { Protection of shea trees } & \\ \text { Dawadawa making } & * * * & \text { Protection of dawadawa } & \\ \text { Wood cutting } & * * * & - & \text { Deforestation }\end{array}$

Source: Fieldwork, 2000

Larger households tended to own more garden units because of abundant labour and stronger networks with other families that enable reciprocal assistance in executing major tasks (75\% of households from survey 1999). This group protects economically valuable trees because the women make a living from exploiting this resource as raw material for making market bound products. Fuel wood harvesting is a major activity for the women in this group. They harvest wood from common property and free-access lands and also trade in agricultural produce in markets in Navrongo, Chiana and Paga. Bush fires on grazing lands close to settlements are blamed on this group, and the ultra-poor who get drunk on market days and throw burning tobacco on bushes along footpaths. Also the poor, in an attempt to smoke out wildlife, intentionally cause bush fires with devastating results (reported in all focus group discussions).

The ultra-poor own small parcels of land on second ring lands in addition to compound farms (Table 6). Labour and resources for expansion is the limiting factor and not land fragmentation as postulated by the literature. Poor yields of crops characterise both land categories indicating soil infertility, which is often associated with severe erosion. They possess small number of livestock, which cannot produce the manure needed for fertilising the land while remittances are not forthcoming from migrated members. Fuel wood harvesting is a major source of income while wild fruits constitute a major source of food security. Fuel wood is gotten from their own farms in addition to common property lands. The very poor are forced to abandon their fields and labour for the rich in order to earn income needed to buy inputs for their farms. This reduces the time and attention needed to sustain the traditional farming system that preserves the environment. The loss of entitlements of this group is initially started by high expenditure and falling incomes which necessitate out-migration of strong male members. The resultant decrease in assets, such as livestock and labour lost, decreases their ability to invest in regenerative land management. Depletion of initial endowments is very critical in the impoverishing process, which is difficult to stop unless migrants are successful.

TABLE 6

Livelihood activities of the ultra-poor and the relationship with land degradation

\begin{tabular}{|c|c|c|c|c|}
\hline \multirow[b]{2}{*}{ Wealth group } & \multirow[b]{2}{*}{ Investment item } & \multicolumn{2}{|r|}{ Environmental Impacts } & \multirow[b]{2}{*}{ Negative effect } \\
\hline & & Rank & Positive effect & \\
\hline \multirow{4}{*}{ The } & On-farm & & & \\
\hline & Manure & $*$ & Good soils & - \\
\hline & Fertiliser & & Increase fertility & Loose soils \\
\hline & Hoe and bullock ploughing & $*$ & Good soil structure & - \\
\hline \multirow[t]{10}{*}{ Ultra- poor } & Tractor ploughing & - & Check erosion & Loose soil, devegetation \\
\hline & New crop varieties & $*$ & Suited to soil & Exhaust soil \\
\hline & Tree planting & - & Improve climate \& soil & - \\
\hline & $\begin{array}{l}\text { Erosion control- bands, } \\
\text { furrows }\end{array}$ & - & Good soil & - \\
\hline & $\begin{array}{l}\text { Garden construction } \\
\text { Livestock rearing }\end{array}$ & $* *$ & Good management skills & Affects other places \\
\hline & Cows & - & Manure, ploughing & Reduces vegetal matter \\
\hline & Sheep & - & Manure & Not very bad \\
\hline & Goats & $* *$ & Manure & Overgrazing \\
\hline & Poultry & $* * *$ & Manure for vegetables & - \\
\hline & Non-farm & & & \\
\hline
\end{tabular}




$\begin{array}{llll}\text { Pito brewing } & * & \text { Income } & \text { Extensification } \\ \text { Alcoholism } & * * * & - & \text { Bush fires } \\ \text { Shea butter making } & * * & \text { Protection of shea trees } & \\ \text { Dawadawa making } & * * & \text { Protection of dawadawa } & \\ \text { Wood cutting } & * * * * & \text { Income } & \text { Devegetation }\end{array}$

Source: Fieldwork, 2000

Are the links real?

\section{Discussion}

The study reiterates the fact that land degradation results from forces emanating from macro level policies and natural processes aided by human practices. The results of the study show that poverty does not necessarily cause land degradation. Rather, the forces or incentives from macro factors at any given time determine the type of practice or treatment the land will be subjected to. The rich and the very poor cause more land degradation than the non-poor and the poor. Each of the wealth groups identified had their distinctive, though crosscutting characteristics regarding their relationship with land. These characteristics are elicited by looking at their land management and investment patterns on land. These are in turn explained by their budgets, which are dictated by the socio-economic situation of the country.

The toll exerted by the difficult economic atmosphere of Ghana is reflected in the need to expand food production. Expanding food production is achieved in two ways; one is expanding the area cultivated and the second is intensifying the use of already cultivated lands. The well-todo groups have the opportunity to expand production because of the advantage of larger entitlements, which they possess over the poor. Both agricultural intensification and extensification is practised by the well to do, while the poor have little possibilities for extensification but possess reasonable levels of assets for intensification. Extensification leads to land degradation through devegetation, bush burning and mechanical tillage. Intensifica-tion involving chemical fertilizers has been known to have adverse effects on the land. Also, intensification without adequate levels of fertilizers - natural or artificial - has adverse effects on land that is synonymous to desertification.

Agricultural extensification and intensifi-cation are caused by the general socio-economic condition of the country. The introduction of a neo-liberal path to develop-ment with its stress on the role of the market has led to the commercialisation of the economy. Removal of subsidies in the face of stiff competition by cheap foreign agricultural products has reduced the ability of the poor to engage in rewarding and good land management techniques while the rich who struggle to meet their cost levels resort to environmentally unsustainable practices to keep them in business.

Poverty is but one factor that determines the way individuals use the land. Poverty's influence on land-use is not uniform since it is subject to variations, whose intensity is crucial in the analysis. The level of poverty has a higher explanatory value than poverty as single variable. The poor in the study area were seen to employ probably the best land-use practises in an attempt to continue the sustainable agricultural practices of their ancestors. Agricultural intensification with the use of minimal chemical fertilizers characterised this group. Well-to-do groups had a lesser degree of agricultural intensification because of the availability of more land that necessitated the substitution of some level of mechanisation for labour and chemical inputs for natural regeneration practices.

The very poor seem to lend credence to the poverty-environment hypothesis. Stack poverty makes people resort to the destruction of common property under the cover of darkness and the destruction of their own lands through over-cultivation and harvesting of vegetation. Some amount of resources or entitlements is necessary to ensure good land management. On the other 
hand, the abundance of some resources in the hands of people who do not have the managerial ability, coupled with scientific inputs to manage and maintain them, also lead to bad land management.

Naturally occurring processes such as drought, floods and black fly infestations have had significant impacts on land degradation or improvement. Droughts are a recurrent feature of the area with devastating impacts on vegetation, soil and animal husbandry. Bush fires that destroy the land during droughts are incomparable to any human land-use type. Floods have turned the surface of the landscape into an architectural drawing of gullies and channels that are hardly used as water channels. Vegetation and the rich top soil are carried away during floods, thereby, causing land degradation.

As opposed to poverty-environment hypothesis, improvement in income of the people is a necessary step but not a sufficient condition for good resource management. This is because of the fact that several factors and not just the amount of money determine resource management possessed by the land user. Also, poverty does not emanate only from land degradation but from increases in the general expenditure or cost of living of the country that has been exacerbated by the introduction of neo-liberal policies.

Cultural factors, rather than only economic reasons, propel population growth in the area. Education is the major factor that breaks the desire to have more children rather than wealth. A rich illiterate does not see the need to cut down his family size when he feels he can cater for all of them. Family planning is even being interpreted as giving birth to the number of children one can cater for and not a conscious effort to reduce dependency burdens and increase human welfare. A policy of increasing income through economic growth will not reduce population growth. It has to be backed by a vigorous educational campaign to instil into the people the need to change their traditional notions of large families.

The range of strategies resorted to by the rural people do not support the poverty-environment hypothesis even though some wealth groups might lend credence to it. The strategies are mainly geared towards reducing expenditure or increasing income to ensure normal livelihoods. The dominant investment item has been garden making, which is a perfect example of agricultural intensification that is needed in the face of growing populations. Livestock investments, contrary to the literature, has overriding benefits for the environment by providing manure, increasing income for further investment and reducing bush fires. Strategies that are deleterious to the environment are used by all categories of wealth groups.

The research findings provide little support to the hypothesis under study and reveal many dimensions of previously generalised problems. Poverty comes into the picture only when one separates it from larger processes and tries relating it to land degradation. In that case the advantages one derives from an integrative study that encompasses several factors in a chain-like fashion is lost.

\section{Conclusion}

It is realised that socio-politico-economic forces emanating from the macro and micro levels carve out livelihoods of peasants. These forces dictate the survival strategies, investment patterns and management practices of land that defines the land-use pattern of the area. Land-use in turn determines the environmental status of the land. The study gives an account of the relationship the wealth groups identified have to land and land degradation. All the wealth groups engage in practices that both destroy and build the environment albeit in different proportions. The rich, in a bid to increase production in an increasingly difficult economic landscape, extensify agricultural production with consequences such as deforestation and lost of soil structure.

The investments people make are constrained by their entitlements and dictated by the socioeconomic condition of the district and nation. The survival strategies and investment patterns lead to both land improvement and land degradation. Asset levels or endowments or access to 
environmental resources, which are of overriding importance in peasant livelihoods, are defined and shaped continuously by institutional rules and norms, weather vagaries and globalisation of trade and government policies. The ability of peasants to engage in environmentally friendly activities depends heavily on their asset levels. However, being non-asset poor does not automatically lead to environmentally sound practices, as shown by the activities of the rich and non-poor wealth groups in this case study. Improvement in income of the people is a necessary step but not a sufficient condition for good resource management.

\section{References}

Abdulai C. and Delgado C. L. (1995). Re-establishing agriculture as a priority for policy in Sub-Saharan Africa. International Food Policy Research Institute, Washington D.C.

Agrawal A. (2001). Common property institutions and sustainable governance of resources. Wld Dev. 29(10): 16491672.

Ahmed I. I. and Lipton M. (1997). Impact of structural adjustment on sustainable rural livelihoods: A review of the literature. Working Paper 62. Institute of Development Studies, Sussex.

Ampadu-Agyei O. (1988). Bushfires and Management Policies in Ghana. EPA Publication, Accra. pp. 221-228.

Beck T. and Nesmith C. (2000). Building on the poor people's capacities: The case of common property resources in India and West Africa. Wld Dev. 29(1): 119-133.

Behnke R. H. and Scoones I. (1993). Rethinking range ecology: implications for rangeland management in Africa. Range ecology and disequilibrium- New models of natural variability and pastoral adaptation in African savannas. (R. H. Behnke, I. Scoones and C. Kerven, ed.) Overseas Development Institute \& IIED. London.

Biswanga P. and Landell-Mills P. (1995). The World Banks Strategies for reducing poverty and hunger. A report to the development community. Environmentally Sustainable Development Studies and Monographs Series No. 4. World Bank, Washington D.C.

Blaikie P. (1985). The political economy of soil erosion in developing countries. Longman, London.

Boserup E. (1965). The conditions of agricultural growth: the economics of agrarian change under population pressure. Aldine Publishing Company, Chicago.

Boyd C. and Slaymaker T. (2000). Re-examining the 'More people less erosion' hypothesis: Special case or wider trend? Overseas Development Agency.

Brown L. R. (1989). State of the world 1989: A World Watch Institute report on progress towards a sustainable society. Norton, New York.

Brown L. R. and Hal K. (1994). Full house - Reassessing the earth's population carrying capacity. W.W. Norton and Company, New York.

Carney J. and Watts M. (1991). Disciplining women? Rice, mechanisation, and the evolution of Mandinka gender relations in Senegambia. J. Cult. Soc. 16(4).

Cavendish W. (2000). Empirical regularities in the poverty-environment relationship of rural households: Evidence from Zimbabwe. Wld Dev. 28(11): 1979-2003.

Chambers R. (1983). Rural Development. Putting the last first. Longman, London.

Chambers R. (1994). The Poor and the Environment. Whose Reality Counts. IDS Working Paper 3.

Chambers R. and Conway G. (1992). Sustainable rural livelihoods: practical concepts for the 21 st century. Brighton, IDS Discussion Paper $\mathbf{2 6 9}$.

Dasgupta P. and Måler K.-G. (1996). Environmental resources and economic development. In New Directions in Development Economics. (M. Lundahl and J. Ndulu, ed.) Routledge, London.

Department of Geography and Resource Development (1992). A socio-economic survey in the Upper East Region with reference to drought and desertification control in Ghana. Final report submitted to the Environmental Protection Agency of Ghana, University of Ghana, Legon.

Dickson B. K. and Benneh G. (1970). A New Geography of Ghana. Longman, London.

Eckholm E. and Brown R. L. (1977). Spreading deserts: the hand of man. World Watch Paper. World Watch Institute, Washington, D.C.

Ehrlich P. R. and Ehrlich A. N. (1990). The population explosion. Simon and Schuster, New York.

Forsyth T. and Leach M. (1998). Poverty and Environment. Priorities for research and policy. An overview study prepared for the UNDP and EC. Institute of Development Studies, Sussex.

GSS (2002). 2000 Population and Housing Census. Summary Report of Final Results. Ghana Statistical Services, Accra.

Lambin E. F., Turner B. L., Agbola S. B. and Arild A. (2001). The causes of land-cover change: moving beyond the myths. Global envir. Chan. 11: 261-269.

Leach M. and Mearns R. (1996). The lie of the land. Challenging received wisdom on the African environment. Villiers Publication, London. 
Lein H. (1993). Floods and agricultural change. Some observations from Bangladesh: 1986 -1990. Norw. J. Geogr. 4.

Lele U. and Stone S. W. (1989). Population pressure, the environment, and agricultural intensification in sub-Saharan Africa: variations on the Boserup hypothesis. World Bank, Washington D.C.

Little P. E. (1999). Environments and environ-mentalisms in anthropological research: Facing a new millenium. $A$. Rev. Anthrop. 28: 253-84.

Matlon P. J. and Spencer D. S. (1984). Increasing food production in sub-Saharan Africa: Environmental problems and inadequate technological solutions. AJAE 66(6).

Maxwell S. (1996). Food security: A post-modern perspective. Fd Pol. 21(2): 155-170.

Seini W. A. (1992). Planning for agricultural growth under policies of structural adjustment in sub-Saharan Africa. Planning African growth and development. Some current issues. (E. Aryeetey, ed.), pp. 171-192. ISSER/UNDP, Accra.

Songsore J. (1992). The ERP/Structural Adjustment Programme: Their likely impacts on the distant rural poor in Northern Ghana. Planning African Growth and Development. Some current issues. (A. Ernest, ed.), pp 154-170. ISSER/UNDP, Accra.

Stonich S. C. (1993). I am destroying the land! the political ecology of poverty and environmental destruction in Honduras, Westview Press, Boulder Co.

Taylor D. R. F. and Mackenzie F. (ed.) (1992). Development from within. Survival in rural Africa. Routledge, London and New York.

WCED (1987). Our Common Future. Report of the World Commission on Environment and Development. WCED, Oxford.

World Bank (1986). Poverty and Hunger. Issues and options for food security in developing countries. Washington DC.

World Bank (1990). World Development Report 1990. Oxford University Press, New York.

Yaro J. (2000). Poverty and Land degradation: The case of the Gia-Kajelo community, Kasena-Nankani District of northern Ghana. (MPhil. Thesis.) Department of Human Geography, University of Oslo, Oslo. 